Originalni naučni rad

УДК 811.111'373.43

Primljen: 31. marta 2021.

Prihvaćen: 7. aprila 2021.

Nina Ž. Manojlović ${ }^{1}$

https://doi.org/10.46630/phm.13.2021.51

University of Kragujevac

Faculty of Philology and Arts ${ }^{2}$

Department for English Language and Literature

\title{
NEWLY CREATED BLENDS AND COMPOUNDS IN THE ENGLISH LANGUAGE RELATED TO THE COVID-19 PANDEMIC
}

This paper aims to investigate the possible interpretations of the new expressions in the English language emerging during the COVID-19 pandemic. The current pandemic and the numerous subsequent profound changes in everyday life have proved to be a fertile ground for the creation of various expressions being increasingly used to describe these different social circumstances. The corpus of the study comprises more than 50 expressions that were collected using different internet tools and platforms. Blending and compounding seem to be the dominant processes for creating the recorded neologisms. Interpretation processes of the expressions with more than one meaning were examined within the framework of the Relevance theory. Since the aim of this paper is to examine the interpretation process of expressions that have specific morphological structure (blends and compounds). Since decomposition is an important step in the interpretation of these expressions, an additional goal is imposed - the analysis of morphological processes involved in their creation. The morphological transparency of neologisms (the level or degree of identifiability of the splinters and bases) is related to our ability to interpret them in the intended way. Furthermore, the interpretation is undoubtedly easier in an appropriate/available/specific context, but this study points to the possibility of the context being as important in the interpretation of compounds (more morphologically transparent) as it is with blends (less transparent). Namely, the neologisms analyzed in this paper comprise at least two concepts and in order to arrive at the intended meaning of an expression, the hearer needs to construct an ad hoc concept, and therefore access the encyclopedic entries of the concepts utilized in creating the neologism. Choosing the correct (intended) properties from the encyclopedic entry, now featuring in a newly created concept, is strongly influenced by the context. This could be one of the reasons for the fact that numerous novel expressions in the English language have more than one meaning (hence interpretation) attested by their recorded use.

1 manojlovic.nina@gmail.com

2 The paper was written within the project The Dynamics of Structures of the Contemporary Serbian Language financed by the Ministry of Education, Science and Technological Development of the Republic of Serbia (ON-178014). 
vance Theory

Keywords: neologisms, ad hoc concept, inference, blending, compounding, Rele-

\section{Introductory remarks}

The COVID-19 pandemic has had far-reaching consequences around the world. People have found themselves in unfamiliar situations where they are obligated to stay at home. Even if they do go out they are advised to distance themselves from others and to wear masks. A great number of people started working from home, some lost their jobs and children started doing schoolwork online, which has significantly changed the day-to-day dynamics of many households. At the time this paper is written, the pandemic will already have lasted a whole year with little or no sign of ending any time soon. This has led to the emergence of specific vocabulary used to describe (often in a humorous manner) the new state of affairs in the world.

This paper aims at exploring the interpretation mechanisms of newly created expressions related to the COVID-19 pandemic in the English language. This specific area of interest is chosen because of the peculiar, one might say unique, situation that we observe today. Namely, the pandemic is a global phenomenon and English is the language of global communication and science, therefore, a significant portion of the information regarding the ongoing pandemic is processed via English. This is why the greatest number of neologisms and terminology related to COVID-19 can be found precisely in English. Certain well-established terms (lockdown, social distancing, pandemic, self-isolation, etc.) became part of everyday language in the media. However, the primary interest of the present paper is in the expressions never heard before the pandemic.

The analysis will focus on blends and compounds for two reasons these processes proved to be the most productive within the examined corpus, and such expressions involve at least two concepts. The presence of two or more concepts is expected to make the interpretation procedure more complex. This is important because we aim to show that the ability to identify splinters and stems easily is not always enough to identify the overall meaning of a newly formed expression. Other studies concerned with how neologisms are processed (LEHRER 2003; LEHRER, VERES 2014; HALUPKA REŠETAR, LALIĆ KRSTIN 2012) mainly focused on the identification of the underlying compound (the splinters) of a blend. Even though the importance of context has been recognized in research concerning neologisms, especially blends, it was merely to point out that the identification of the underlying compound did not significantly speed up the processing time. When analyzing the pragmatic aspect of neologistic blends Lehrer points to perlocution, i.e. intention to grab the readers' attention and be memorable. She even suggests that "novel blends 
are not just like other novel compounds" (2003: 380) and that the creator of a blend does not want the recipient to process it quickly. In fact, a slower response is desirable since the goal is to make a blend memorable. In this paper we intend to go beyond splinter identification and attempt to exemplify how the interpretation process of compounds as well as blends would unfold, especially in those instances where different meanings of the same expression were attested. This small-scale research seems to suggest that novel compounds resemble novel blends more than was previously discovered in relevant literature, at least when it comes to inferences that follow decomposition.

The data for this study were collected through various Internet sources. The majority of examples were excerpted from Urban Dictionary ${ }^{3}$ and Dictionary.com ${ }^{4}$, since these platforms instantaneously record changes in recent lexis. Furthermore, dictionaries offer sample sentences, i.e. expressions in use, providing potential contexts for interpretation. Therefore, it was decided to limit the analysis to the expressions excerpted from the two dictionaries. All the collected expressions are newly created linguistic units that arose during the pandemic and are semantically related to the pandemic. Since the aim of this paper is to examine the interpretation process of expressions that have specific morphological structure (blends and compounds) and since decomposition is an important step in the interpretation of these expressions, an additional goal is imposed - the analysis of morphological processes involved in their creation. Hence, these novel blends and compounds were first analyzed in terms of their morphological characteristics and then the accessibility of their intended meaning was examined.

The pragmatic part of the analysis will rely on the Relevance-theoretic (RT) approach (SPERBER, WILSON 1986; CARSTON 2008), since, to our knowledge, this pragmatic apparatus has never been used to explore the difference between inferential processes involved in interpreting blends in contrast to compounds. In addition, this theoretical framework provides us with the tools to examine the ways in which the context guides the inferential process and what its role is compared to the criteria of transparency ${ }^{5}$. Namely, according to RT there is a gap between the linguistically encoded meaning of an utterance and the speaker's meaning. This gap is set off by the discrepancy between the meaning of a word (the encoded meaning) and its meaning when the word is used in a specific context (the communicated meaning). The speaker's meaning is thus dependent on the context. Therefore, the aim is to inspect how the hearer could bridge the gap in order to arrive at the intended

3 https://www.urbandictionary.com/

4 https://www.dictionary.com/

5 In this paper, the term transparency relates to the identifiability of stems (in compounds) and splinters (in blends). 
meaning. RT is based on the principles of effects and effort - relevance is proportional to cognitive effects achieved and inversely proportional to the cognitive effort needed. The neologisms (blends and compounds) that are the subject of this study are specific in that they often require additional processing effort (LEHRER 2003), since they are constructed to refer to novel everyday circumstances in a humorous manner and as attention grabbers. Therefore, it is expected that cognitive effects achieved by their use are worth this additional effort. It is suggested here that the additional cognitive effects are warranted by the use of (at least) two concepts. Namely, since blends and compounds imply the existence of two or more lexemes, the pragmatic process involved in the interpretation will be applied to two or more concepts. So, the processes of lexical narrowing (strengthening) and broadening (loosening) are applied to at least two concepts in order to yield the intended ad hoc concept. It is expected that the context will dictate which parts of the encyclopedic entries of the concepts involved will be chosen and which ones dropped. This is the reason why a pragmatic analysis was applied to those expressions that were found to have more than one recorded meaning. Likewise, expressions that are culture-specific were also subjected to pragmatic analysis, since their potential interpretation is heavily dependent on background knowledge (i.e. communal common ground), so whether these expressions are interpretable solely on the grounds of linguistic context (i.e. co-text) needs to be examined. It is also important to note here that the interpretation of the expressions analyzed in this paper will also (perhaps primarily) be guided by the global context of the ongoing pandemic shared by speakers around the world (apart from situational, linguistic and common ground context).

\section{Theoretical considerations}

Bussman (1996) defines a neologism as "a newly formed linguistic expression (word or phrase) that is recognized by at least part if not all of a language community as the way to denote a new object or state of affairs, be it in technology, industry, politics, culture or science", while Newmark defines it as "newly come lexical or existing units that acquire a new sense" (1988: 140). Bauer (2001: 67) states that neologism is a natural phenomenon of language responsible for its productivity. Various definitions of neologisms seem to point to two common notions: the notion of creating novel items (words or phrases) that never existed in the linguistic repertoire of the language or community and the notion of shift in meaning of already existing linguistic items. Therefore, these expressions either apply to new concepts/notions or synthesize pre-existing concepts. Whether these recent items become stable in a language, that is, whether they enter the vocabulary of a language communi- 
ty, depends on various factors.

Gryniuk (2015: 150) notes that the process of lexicalization of neologisms should not be regarded as coincidental since neologisms are prone to going through certain stages of transformation. Namely, neologisms begin as unstable creations (protologisms), being proposed, or being used only by a small subculture. The expressions analyzed here were created due to current social reality - the COVID-19 pandemic. This pandemic exists on a global level and people are communicating and sharing their thoughts online, coining and using new expressions frequently, so these expressions seem to go through these stages (from protologism to neologism) fairly quickly. Even though they are created by a small community, they spread very fast via Internet communities.

\subsection{Compounds and blends}

New words are created through different morphological processes. In the corpus of this study blending and compounding proved to be most frequent, apart from a few examples of change in lexicalized phrasal units and clipping (for detailed account of attested examples see section 3), hence they are the focus of the analysis.

A compound is a combination of two (or more) lexemes (BAUER 2003). Most frequently, new nouns (bullfrog, mailbox, peanut butter, passer-by) and adjectives (well-known, long-distance, world-famous, sun-dried) are formed in this way, with the $\mathrm{N}+\mathrm{N}$ model being most commonly used.

Certain compounds are more semantically transparent than others. The notion of semantic transparency refers to the degree to which the overall meaning of an expression can be linked to the meaning of its constituents and the way they are combined (SCHÄFER 2018). In the majority of cases, the meaning of a compound noun is a specialization of the meaning of its head. This is easier with endocentric compounds (dining-table is a type of table, bedroom is a type of room) than with exoteric ones (highbrow is not a type of brow, hothead is not a type of head). There are, not so infrequently, compounds that consist of more than two lexemes (power source requirement, communication technology equipment, engine communication error), which may be even more difficult to process (i.e. their meaning is less transparent). Plag (2003: 134) notes:

There is no structural limitation on the recursivity of compounding, but the longer a compound becomes the more difficult it is for the speakers/ listeners to process, i.e. produce and understand correctly. Extremely long compounds are therefore disfavored not for structural but for processing reasons.

A blend is also a combination of two or more lexemes, but with material being clipped from one or all of them. Gries defines blending as a process 
that involves the coinage of a lexeme by "fusing parts of at least two other source words of which either one is shortened in the fusion and/or where there is some form of phonemic or graphemic overlap of the source words" (GRIES 2004: 639). However, the status of blending remains a matter of controversy because it verges on compounding (combining of lexemes) and clipping (loss of material) (DANILOVIĆ JEREMIĆ, JOSIJEVIĆ 2019). This situation is additionally complicated by the fact that in certain blends it is not easy to determine which lexeme was clipped due to the overlapping ${ }^{6}$ of material (Chicagorilla - Chicago + gorilla, radarange - radar + range, sexploitation - sex + exploitation). Even though blending is considered a less productive process in English, when it comes to situations that require creativity, blending proves to be the morphological process of choice. Ray (1995: 66) points to the importance of the creators of neologisms, as well as the community, discourse and situation in which they are used. Therefore it is necessary to take into consideration the pragmatic aspect of these expressions in actual communication. Since not all splinters are equally informative and thus transparent (and are undeniably less transparent than bases that make up a compound). Furthermore, given the speed of introduction of numerous expressions in communication, it is expected that at least some expressions will have more than one recorded meaning and context of use.

Even though blends have a condensed meaning and are often used for achieving creativity or humor, the question is why there are so many blends if their intended interpretation is not warranted. Lehrer (2003: 369) believes that the majority of new blends do not increase efficiency and require additional effort in order to be interpreted, at least until the recipients (hearers/readers) figure out what the source words are. However, it is suggested here that another step (apart from identification of concepts involved) is sometimes crucial - ad hoc concept formation, where the hearer needs to narrow or broaden one or all the concepts that are part of a blend or compound in order for the expression to be interpreted in the intended way. This process is guided by the context.

\subsection{Relevance Theory}

In section 3 of this paper, concerned with the interpretation of new expressions, the theoretical framework of the Relevance theory will be applied (SPERBER, WILLSON 1986; CARSTON 2008). Relevance theory is based on the Cooperative and Communicative principle, i.e. the balance between the 6 Here the term overlapping is not used in its broad sense. Normally, overlapping blends are those in which sounds or letters overlap, but still some clipping is involved. For example, the blend smog (smoke + fog) exhibits overlap at the letter $o$, but both involved lexemes (smoke and fog) lose material. Here the term overlapping refers to complete overlapping, where (most commonly) the first word ends with the same sound or sequence of sounds as the second word begins with. 
effort needed for arriving at the intended interpretation and the achieved cognitive effects. The Cognitive principle states that human cognition is directed towards the maximization of relevance, while the Communicative principle presupposes that every act of ostensive communication carries the assumption of its own relevance (SPERBER, WILSON 1986). Therefore, when it comes to production, the speaker produces an output (according to his/her abilities and affinities) in such a way as to reduce the hearer's processing effort. On the other hand, the hearer follows the path of least effort forming interpretative assumptions in the order of their accessibility and stopping the process when the expected relevance is satisfied or cannot be reached (MIŠKOVIĆ LUKOVIĆ 2013: 49). Interpretative hypotheses are tested in order of accessibility and are driven by the achievement of optimal relevance (WILSON, SPERBER 2006).

What is most important for our analysis is how the gap between the encoded and communicated concept is bridged, since the concepts that need to be accessed when interpreting a neologism which is a blend or a compound frequently have to be loosened or strengthened, or both. A lexical concept is a part of the logical form of an utterance, and by means of pragmatic adjustment an ad hoc concept is created, which is the communicated concept and is a part of the proposition. Conceptual address is a mental label connecting and providing access to information of various sorts pertaining to a single concept - logical or computational rules and procedures, encyclopedic information about the denotation of the concept and linguistic information about the natural-language counterpart of the concept. Loosening (or broadening) results in a communicated concept that is more general than the encoded one, and the strengthening (or narrowing) process results in a communicated concept that is more specific than the encoded one (MIŠKOVIĆ LUKOVIĆ 2015: 116). Both processes are driven by the search for relevance.

The interpretation of new expressions relies even more on the context than is the case with already familiar linguistic units. Many of the descriptively used concepts start their journey as attributively used ones. In the scenario depicted in the introductory section of the paper, these new expressions are coming into existence very rapidly and are used by or, at least available to, very broad and versatile audience. This is the main reason why, apart from the morphological analysis, RT was chosen for the analysis of the excerpted expressions. Namely, the overall meaning of blends and compounds depends on the semantics of the bases or splinters. However, the fact that expressions related to COVID-19 are being coined in great numbers over not so long period of time and are being used by speakers with various background knowledge, common ground and L1 had an impact on their usage. Some of these novel expressions have more than one basic (encoded) meaning and recorded use. These expressions, precisely, are believed to be a fertile ground for pragmatic 
investigation on how ad hoc concept construction may take a different path depending on the context. The aim is to examine the narrowing/broadening processes in those instances where the context determines the meaning of a blend or compound.

\section{Analysis}

The examples used for this study are taken from the two dictionaries which, at the time data were being compiled, had recorded almost 50 newly created words related to the COVID-19 pandemic. These expressions were listed in special sections of a dictionary. The examples will be divided according to morphological criteria since these are more precise than the distinction transparent/non-transparent. The analysis will begin with blended structures and then analyze the compounds. No separate sections will be dedicated to clipping, orthographic changes and abbreviation, since we have found one example of each (Rona - Corona; cornteen - quarantine; WFH - working from $h o m e^{7}$ ). Additionally, four cases of change in lexicalized phrasal units (e.g quarantine and chill) and 2 cases of shift of meaning (e.g. Covid meaning a child conceived during the COVID-19 pandemic) were also attested.

Quantitatively speaking, out of 53 collected expressions (including the examples mentioned above), 26 were cases of blending and 18 cases of compounding. These neologisms can be roughly divided into those concerning the type of proper conduct during the pandemic (or the lack thereof) (covidiot, moronavirus), being quarantined and working from home (quarantiny, zoombombing, blursday, quaranteams), the aftermath of being confined (mostly related to additional weight gained during the lockdown) (coronabesity, COVID-10, Corona 20, coronabod, Corona-Broke), socializing and relationships (covideo party, covidivorce, zumping, coromance, zoom and consume), a huge spike in birthrate due to the lockdown (coronababies, quranteens, corona boomer, coronials) and those that apply to miscellaneous categories (coronabhorism, coronarmagedon, doomscrolling).

\subsection{Blends}

The examples of blends excerpted from the various Internet platforms are mainly partially overlapping (overlapping in sound(s) and/or letter(s)) blends. Some examples include:

$$
\begin{aligned}
& \text { quaranteens - quarantine + teens } \\
& \text { coronacation - corona + vacation } \\
& \text { quaranteams - quarantine + teams }
\end{aligned}
$$

7 Although this abbreviation is preexisting, it has recently been linked to discourse about the COVID-19 pandemic (URBAN). 
coromance - corona + romance

coromies - corona + roomies

coron - corona + moron

It is important to note here that, in the cases where the loss of material is substantial, the overlap may resemble a case of clipping (e.g. coron). However, coron cannot be considered to be a shorter name for corona, since it clearly contains the meaning of moron. From the pragmatic perspective, this means that the hearer will have to access two concepts when interpreting the utterance containing the said neologism - CORONA and MORON. The process of ad hoc concept formation is guided by the context of use, as will be discussed and exemplified later on in the paper.

Even though it has been suggested that non-overlapping blends are less preferred than the overlapping ones, because they render reconstruction of the source words more difficult (MATTIELLO 2013: 123), our study cannot fully confirm that. The splinters in the non-overlapping examples we have collected are, in the majority of cases, as easy to identify as is the case with the overlapping ones. For instance:

$$
\begin{aligned}
& \text { coromania - corona + mania } \\
& \text { covetiquette - covid + etiquette } \\
& \text { coronalationship - corona + relationship } \\
& \text { covexit - covid + exit }
\end{aligned}
$$

However, some examples of non-overlapping blends did in fact have splinters that were much more difficult to identify because too much material is dropped (e.g. zumping - Zoom + dumping), which would then render their interpretation more difficult. So the issue is not about whether the splinters overlap but rather about how much of a splinter is retained, i.e. whether it is enough to reconstruct the item. Nevertheless, the role of context is of crucial significance in arriving at the intended interpretation of neologisms, especially in cases where several interpretations are possible. For instance, for this precise blend the example of use provided is:

1) I will plan on zumping my girlfriend today. (URBAN)

The intended interpretation is [The speaker] will plan on [dumping via Zoom] [the speaker's] girlfriend [the day of the utterance]. One could presume that, based on a personal common ground (the shared knowledge between the interlocutors about the speaker and the speaker's girlfriend, as well as the state of their relationship), communal common ground (that much of the communication during the pandemic is taking place via platforms like Zoom) and the linguistic context, the hearer might be able to work out the overall meaning of 
the used blend, even though the morphological transparency is low to nonexistent. As stated previously, there is a correlation between morphological transparency and the ability of the hearers to interpret them in the intended way, but this analysis is also aimed at investigated to what extent can context play a bigger role in interpretation than is the role of transparency. In the case of zumping, the context seems to be more important than identification of splinters.

Apart from this, a fairly large number of completely overlapping blends was identified (considering the fact that they are not that common):

$$
\begin{aligned}
& \text { covidiot }- \text { covid }+ \text { idiot } \\
& \text { covidivorce }- \text { covid }+ \text { divorce } \\
& \text { coronarmageddon }- \text { corona }+ \text { armageddon } \\
& \text { coronapocalypse }- \text { corona }+ \text { apocalypse }
\end{aligned}
$$

Certain blends contain orthographic changes. For example, on numerous occasions, we have found an alternative spelling coronarmagedon (coronarmageddon). These changes might be due to stylistic reasons, or, perhaps, due to the fact that the creators of the corona-related neologisms are not necessarily native speakers of English, so these orthographic discrepancies might be the result of an incorrect spelling of a word. Some orthographic changes seem to be deliberate simplification and/or euphemization (e.g. letter $y$ in quarantiny - quarantine + martini). In terms of possible pragmatic contribution the changes might contribute to additional cognitive effects through triggering the recovery of certain weak implicatures, such as emotive relation to an alcoholic drink during the pandemic (rel. quarantiny).

There was one example that can be considered a blend with complete overlapping due to the spelling of its splinters, but the pronunciation is completely different so it cannot be ignored - COV-ID $(C O V I D+I D)$. Apart from these different pronunciations (/, kəv.VId/ and /,ai di:/) the hyphen marks a sort of visual barrier between the splinters. In addition to this example, only one more hyphenated blend (with an infix) was found-zoom-a-rific (Zoom + terrific), which is a play on orthography for stylistic reasons.

Aside from the morphological transparency which correlates with the ability to identify the splinters, the meaning of some neologisms was found to be highly dependent on the context of use. Namely, certain novel blends have more than one usage with a different meaning. One example is the blend quaranteens (quarantine + teens) with fairly easily identifiable splinters. The hearer of an utterance containing the given expression is invited to access the encyclopedic entries of the two concepts that took part in the formation of the blend. It is expected that this new ad hoc concept contains parts of the encyclopedic entries of quarantine and teen(ager)s. However, this proved not to be sufficient, 
since two different meanings of the blend were found in two different dictionaries used as sources for this study:

2) Babies being conceived while people are cooped up at home during the coronavirus have been dubbed coronababies. And when these babies get older, they will become the quaranteens; (DICTIONARY)

3) Kids born between 2001 and 2007, who were technically teenagers during the Covid-19 quarantine period in 2020. (URBAN)

Even though the pragmatic processes applied are the same, the relation between the concepts is established differently. Namely, the concept QUARANTINE is narrowed to mean specific QUARANTINE* during COVID-19 pandemic and the second concept can be taken descriptively (children in their teenage years) or as a loosened concept (children in roughly/approximately teenage years). However, the overall meaning of a blend frequently depends on the relation between the two (or more) communicated concepts. Even though one meaning tends to be a more likely one, i.e. the meaning in 3 ) is the expected meaning, the existence of another meaning recorded by a different dictionary points to several issues. The most important issue for this study is how the hearer can arrive at the intended meaning if there are, in fact, two different meanings of a newly coined expression. It is clear that different parts of encyclopedic entry of one or both concepts contained in the neologism will be accessed, and that context (linguistic or otherwise) provides the necessary input for the process of ad hoc concept formation. This will be exemplified by analyzing the expression in question when used in context:

3a) Some quaranteens were scared they wouldn't graduate because of the virus. (URBAN)

The interpretation of utterance in 3a), following the path of least effort, would imply the pragmatic process of ad hoc concept construction, guided by background information (that there is a global pandemic at the time and people are in mandatory self-isolation/quarantines) and contextual information (that it refers to persons at the age of graduating). Therefore, the first accessible interpretation that satisfies the expectation of relevance would be TEENAGERS IN QUARANTINE*. Ultimately, again depending on the context, the term quaranteen could yield a different interpretation. By the process of lexical broadening, it could be used to refer to people other than the teenagers, but who are acting like ones. However, this was not confirmed by our corpus.

There might be two possible reasons for this and similar discrepancies in the use of these newly created expressions in English. Firstly, due to the global situation explained in the introductory section of the paper, we cannot dismiss the possibility that the same expression originated at the same time 
but in different communities, hence possibly having different meaning. Another reason, independent of pandemic-related circumstances, might be that the new concept (as is the case with so many newly acquired concepts) is used attributively ${ }^{8}$, hence prone to be used inadequately. This new meaning can begin a life of its own if accepted in a community.

Similarly, blends like coronacation and quaranteams were recorded in different usages and meanings in our corpus. ${ }^{9}$ Let us look at two definitions and examples of use of the blend coronacation taken from the two dictionaries:

4) Coronavirus-compelled staycations, due to cancelled classes, shifts, and the like. It's usually an ironic term-just ask parents working from home while teaching their kids. (D1)

4a) My teen thinks he's getting a coronacation since his school has moved online. Oh, wait until he sees how I am going to keep him busy with Dictionary.com's Learning At Home resources.

5) A coronacation is a vacation that takes place because of cheap flights and hotels that exist because of the 2020 coronavirus. (D2)

$5 a)$ Because of the coronavirus I can buy an airline ticket to Burkina Faso for $\$ 13$ as a spring break coronacation.

As can be seen from the definitions, both new concepts incorporate properties from the encyclopedic entries of corona ${ }^{10}$ and vacation. However, it is the context (see examples $4 \mathrm{a}$ and $5 \mathrm{a}$ ) that points to the interpretation vacation at home during/due to Corona or cheap destination vacation due to Corona. In the first example (4a) the encyclopedic entry of the concept VACATION is being exploited in that most of its properties enter the overall meaning of the ad hoc concept (relaxing, doing very little to nothing, etc.). However, the co-text directs the hearer to infer that the said vacation is at home, due to the quarantine (since his school has moved online). In the example 5a the same properties of the concept VACATION are emerging, but the co-text (the immediate linguistic context) is guiding the inferential procedure towards a different ad hoc concept construction. By mentioning the cheap airline tickets the intended meaning is moved towards a different type of vacation. The most interesting finding

8 Attributive concepts are ad hoc concepts where the speaker dissociates herself from the descriptive content of the lexical concept and attributes it to someone else (MIŠKOVIĆ LUKOVIĆ 2015: 129) or concepts used to represent a concept the speaker need not fully understand or endorse, hence takes no responsibility for the truth of the descriptive content of the concept.

9 It should be noted that blends that are not that transparent could hardly be interpreted without abundant and adequately informative context (e.g. zumping - Zoom + dumping and coronabate - Corona + masturbate).

10 It might be important to note that in all the examples with the concept Corona, the concept is narrowed to mean only the corona virus that is currently causing a pandemic (i.e. COVID-19). 
here is that, in both cases, the overall meaning is close to [proper] vacation due to Corona pandemic. However, it is evident that immediate context restricts the inferential procedure to a more specific meaning. These pragmatic processes are triggered by the search for relevance and the least effort strategy ${ }^{11}$, in order for the hearer to arrive at the intended meaning of the expression.

\subsection{Compounds}

When it comes to processing compounds, the identification of their parts should not be an issue. Perhaps this is the reason why research dealing with the interpretation of neologisms has not dealt much with compounds in this sense. However, the corpus of this study shows that compounds can have more than one meaning, too. Before the possible sources of (mis)interpretation are analyzed, some morphological aspects of the identified compounds will be presented.

Compounds found to be coined recently, during COVID-19 pandemic, are most frequently open compounds, i.e. they comprise two separate words:

\section{zoom bar corona boomer \\ Corona beard \\ Corona Ass \\ COVID Thirst \\ Corona bae}

As can be seen from the selected examples, they do not follow any regular patterns of capitalization. Both bases can be written in lowercase (e.g. corona boomer), one word can be capitalized (e.g. Corona bae) or both (e.g. Corona Ass). There are also examples where the uppercase was retained for all letters of the word COVID, due to spelling of COVID-19. Some compounds represent a play on the name of the virus. For example, COVID-15 is a riff on the numerals of COVID-19 and the expression freshman 15, used to refer to the weight some people gain during their first year of college.

Within our corpus, only three hyphenated compounds were attested: doom-scrolling, Corona-Broke and corona-blocked (with alternative spelling $C$-blocked), again exhibiting variation in terms of capitalization. There were fewer closed compounds in the corpus:

\section{doomsurfing}

11 The relevance-theoretic comprehension procedure is called the least-effort strategy: (i) check interpretations in order of their accessibility, that is, follow a path of least effort; (ii) stop when you find an interpretation which satisfies your expectation of relevance. 


\section{zoombombing \\ coronababies \\ coronabinging}

Some orthographic rules may differ depending on the Internet source (zoombombing or zoom-bombing or Zoombing) and certain closed compounds have their open counterparts that were also found in use on the Internet (eg. coronbabies or corona babies, doomsurfing or doom surfing). Furthermore, when used as a hashtag, the first letters of the bases in closed compounds sometimes become capitalized (e.g. \#CoronaBinging).

Apart from these, there are certain examples of combination of blends and compounds. For instance, the closed compound moronavirus comprises a blend morona (corona + moron) and the lexeme virus. An additional example is the open compound covideo party, which comprises an overlapping blend covideo (covid + video) and party.

When it comes to the interpretation of compounds, the identification of bases should not be an issue. The parts of a compound should be easily identifiable, unless it is a combination of a blend and a compound. However, as was the case with the analysis of the interpretation of blends, even when the building blocks of a certain novel expression are identifiable, the context is sometimes needed to determine which properties from the encyclopedic entries are to be selected and how these concepts are to be combined.

Interestingly, only one compound was found to have different meanings - moronavirus. This does not mean that the interpretation of compounds is necessarily easier than the interpretation of blends, as we will try to demonstrate using examples of culture-specific concepts (as those in the compounds COVID-10 and Corona 20) and examples where very specific properties are taken from the encyclopedic entry of a concept (e.g. the case with COVID Thirst or Corona Ass).

Firstly, the issue of the compound moronavirus is multilayered. On one interpretation it is synonymous with the previously mentioned covidiot, referring to someone who does not behave accordingly during the Coronavirus pandemic:

6) My roommate is being such a moronavirus. He went down to the beach with a huge group of friends. (URBAN)

In this reading, the first part of the compound is a blend of moron and corona. However, the compound moronavirus is found to mean a virus that affects the stupidest of people. Makes them act irrational, wreckless, and like a moron (URBAN). On this reading, the first part of the compound cannot be taken as a blend, and the said compound has an infix (moron-a-virus), since 
this meaning of the expression moronavirus predates the current pandemic and cannot be linked in any way with the concept CORONA.

Furthermore, there are examples where the pragmatic processes of loosening and strengthening have to rely on a specific context that is required for the interpretation of such expressions. Compounds like COVID-10 and Corona 20, for example, require specific knowledge about the expression freshmen 15:

7) COVID-10, also referred to as the COVID-15 or even the COVID-19, is a riff on the numerals of COVID-19 and the freshman 15, an expression for the weight some people (are said to) gain during their first year of college. (DICTIONARY)

However, when put in context, arriving at the intended meaning, even without the knowledge of the expression freshman 15, becomes possible:

7a) I really need to get back to the gym and burn off this Corona 20. (URBAN)

Here the speaker is invited to search for relevance using contextual assumptions regarding the reasons people go to a gym and what they are usually trying to lose/burn off. This is how the numerals become extremely narrowed to convey the number of pounds one needs/would like to lose.

In a similar manner, certain compounds require a clear context in order for optimal relevance to be achieved. This is due to the very specific and restrictive use of a lexeme, where only a small portion of the encyclopedic entry of a concept emerges as relevant for the interpretation of the expression. For example, the lexeme ass has numerous meanings, hence the context is needed for the pragmatic process of disambiguation - whether it applies to a person (in which case the hearer is to search for relevance within the realm of people not behaving properly or accordingly) or to a part of a human body (in which case the speaker is to search for relevance within the properties contained in the encyclopedic entry of the concept Ass2) or to the animal, etc. Only in context, it being a newly formed and so far non-existing expression, can the hearer arrive at the intended interpretation:

8) I haven't left the house in 7 days, my head really itches, and I've got a severe case of corona ass. (URBAN)

Again, relying on contextual assumptions, the hearer can interpret the compound Corona Ass as referring to the smelly, unkempt state someone is in whilst sitting in quarantine at home with no real reason to take a shower (UR$\mathrm{BAN})$. This precise interpretation is triggered by the use of expressions my head really itches and haven't left the house in 7 days found in the co-text. Speaking in 
terms of underdeterminacy thesis and ad hoc concept construction, one could imagine that the said blend might have a different interpretation, although not attested in the corpus of this study. For example, the context might suggest that Corona Ass has an overall meaning similar to that of covidiot (e.g. My friend is such a Corona Ass, he refuses to wear a mask even in a supermarket), which further stresses the importance of context.

\section{Conclusion}

Neologisms have been mostly dealt with in terms of their morphology and their meaning (the semantic aspect). Novel blends have been investigated in terms of their processing, i.e. the speed and accuracy of identifying blends (LEHRER 2003; LEHRER, VERES 2014). Lehrer and Veres (2014) tested this with stem completion and a lexical decision task, but the results were inconclusive. Lehrer (2003: 380) suggests that understanding blends is intended to be more difficult than understanding compounds due to the perlocutionary intent, and that blends are to be compared to literary tools (metaphor, metonymy and other figures of speech) in that they all have an aesthetic goal. We attempted to investigate blends and compounds beyond the issue of decomposition.

This paper examines newly created blends and compounds in the English language both from a morphological and pragmatic aspect (i.e. the issue of their interpretation). The corpus of this study is specific in that it comprises numerous very recent neologisms referring to a global event, which has several implications. Firstly, these expressions have emerged quickly and in large numbers, sometimes even simultaneously, resulting in different meanings in different communities. The second very important consideration to be taken into account is that not all of these expressions originated from speakers whose L1 is English. Thirdly, due to the fact that the pandemic is a global and very current event, these expressions usually enter the language quickly and become widespread at a much faster pace than is usual for neologisms in general. All these properties of COVID-19 related neologisms were the reason for investigating how the interpretation of these expressions is affected.

Morphologically speaking, the neologisms analyzed are mainly blends and compounds, so the analysis focused on these structures. Blended structures were somewhat more frequent than compounds, which might point to a trend or inclination towards blending over compounding in the contemporary English language, but the data collected for this study is insufficient to make any such claim. Both overlapping and non-overlapping blends were found, as well as closed and open compounds, closed being far less frequent. Numerous orthographic differences were identified in blends and compounds, and even combinations of blending and compounding were attested.

When it comes to the pragmatic aspect of our research, we can con- 
clude that, despite the fact that these expressions refer to a situation that can be taken as globally familiar, common to the majority of people on the planet, immediate linguistic or situational context is sometimes crucial in order for an expression to be interpreted as intended by the speaker, or interpreted at all. In certain cases, the immediate and/or situational context guides the interpretation process in terms of ad hoc concept construction and in some cases even a specific knowledge of cultural peculiarities is needed in order to achieve optimal relevance. However, it has been shown that even in the cases with culture-specific expressions, arriving at the intended interpretation is still possible if the context is informative enough. There have been studies focusing on the interpretation of blends with and without context (see HALUPKA REŠETAR, LALIĆ KRSTIN 2012), however, the focus was on the ability to identify roots. ${ }^{12}$ The analysis in this paper seems to point to the fact that even when the splinters and roots (stems) are identified, some sort of context (immediate linguistic context, background knowledge, communal (common or personal), situational or otherwise) is needed to arrive at the intended meaning of the overall expression. This might be the reason why compounds, as blends, also exhibit the tendency to have different meanings depending on the use. So, from the pragmatic standpoint, it is not sufficient to identify the language units a blend or a compound is made of, but to arrive at the intended emergent property based on the interplay of encyclopedic entries of the concepts involved.

Due to the ever-increasing globalization new language units and information are expected to spread on an immensely large scale. This could lead to, as has been partially shown in this paper, an increase in the misunderstanding of certain expressions. On the other hand, the globalized world and common experiences could lead to greater transparency in terms of shared background knowledge and shared context. Large-scale events, such as the COVID-19 pandemic, triggering changes in language, especially a globally used language such as English, might shed some light on the interpretation of neologisms from the very instance they are coined. Relevance theory could explain in more detail how the inferential processes are guided by the context and search for relevance, and how the intended meaning is arrived at even in instances where the expression used is new to the hearer. This is especially important when it comes to newly coined blends and compounds, since their interpretation involves broadening and/or narrowing of two (or more) concepts.

Works cited

BAUER 2001: BAUER, Laurie. Morphological Productivity. Cambridge: Cambridge University Press. 2001.

12 The authors found that the greatest factor in identifying splinters of a blend in Serbian was the level of English language proficiency (HALUPKA REŠETAR, LALIĆ KRSTIN 2012). 
BAUER 2003: BAUER, Laurie. Introducing Linguistic Morphology. Washington, D.C.: Georgetown University Press. 2003.

CARSTON 2008: CARSTON, Robin. Thoughts and utterances: The pragmatics of explicit communication. New Jersey: John Wiley \& Sons. 2008.

DANILOVIĆ JEREMIĆ, JOSIJEVIĆ 2019: DANILOVIĆ JEREMIĆ, Jelena and JOSIJEVIĆ, Jelena. "The Compounds and Blends in Brand Names of Baby Products." Nasleđe, volume 24 (2019): p. 111-124.

GRIES 2004: GRIES, Stefan. "Shouldn't it be breakfunch? A quantative analysis of blend structure in English.” Linguistics, volume 42 (2004): p. 639-667.

GRYNIUK 2015: GRYNIUK, Dominik. "On Institutionalization and De-Institutionalization of Late 1990s Neologisms." Within Language, Beyond Theories, volume 3 (2015): p. 149-162.

LEHRER 2003: LEHRER, Adrienne. „Understanding trendy neologisms.“ Italian Journal of Linguistics, volume 15 (2003): p. 369- 382.

LEHRER, VERES 2014: LEHRER, Adrienne and Csaba VERES. Experiments on processing lexical blends. <https://alehrer.faculty.arizona.edu/sites/alehrer. faculty.arizona.edu/files/\%20Experiments\%20on\%20Processing\%20Lexical\%20Blends.doc > 02. 11. 2020.

HALUPKA REŠETAR, LALIĆ KRSTIN 2012: HALUPKA REŠETAR, Sabina and Gordana LALIĆ KRSTIN. "Razumevanje slivenica u srpskom jeziku.” Nasleđe, volume 22 (2012): p. 101-110. [orig.] ХАЛУПКА РЕШЕТАР, Сабина и Гордана ЛАЛИЋ КРСТИН. „Разумевање сливеница у српском језику.“ Наслеђе, број 22 (2012): стр. 101-110.

MATTIELLO 2013: MATTIELLO, Elisa. Extra-grammatical morphology in English: abbreviations, blends, reduplicatives and related phenomena, Berlin/Boston: Walter de Gruyter, 2013.

MIŠKOVIĆ LUKOVIĆ 2015: MIŠKOVIĆ LUKOVIĆ, Mirjana. Pragmatika. Kragujevac: Filološko-umetnički fakultet. 2015.

NEWMARK 1988: NEWMARK, Peter. A Textbook of Translation. New York: Prentice-Hall International. 1988.

PLAG 2003: PLAG, Ingo. Word-formation in English. Cambridge University Press. 2003.

RAY 1995: RAY, Alain. Essays on terminology. Amsterdan/Philadelphia: John Benjamins Publishing. 1995.

SCHÄFER 2018: SCHÄFER, Martin. The semantic transparency of English compound nouns. Berlin: Language Science Press. 2018.

SPERBER, WILSON 1986: SPERBER, Dan and Deidre WILSON. Relevance: Communication and cognition. Cambridge: Harvard University Press. 1986.

WILSON, SPERBER 2006: WILSON Deidre and Dan SPERBER. "Relevance Theory." The Handbook of Pragmatics, (eds L.R. Horn and G. Ward, DOI:10.1002/9780470756959): p. 607-632.

\section{Sources}

DICTIONARY: “DICTIONARY.COM”. < <https://www.dictionary.com/e/s/ 
new-words-we-created-because-of-coronavirus/\#1>22.10.2020.

URBAN: "URBAN Dictionary". <https://www.urbandictionary.com/> 22.10.2020.

Nina Ž. Manojlović

\section{NOVE SLIVENICE I SLOŽENICE U ENGLESKOM JEZIKU NASTALE USLED KOVID-19 PANDEMIJE}

$\mathrm{U}$ radu se ispituje interpretacija novih izraza u engleskom jeziku, a koji su nastaju tokom pandemije virusa COVID-19. Trenutna pandemija i brojne prožimajuće promene u svakodnevici pokazale su se kao plodno tle za pojavu raznovrsnih izraza koji se sve češće koriste u jeziku kako bi se opisala novonastala situacija. Korpus na kome je vršeno istraživanje sastoji se od preko 50 izraza ekscepiranih sa raznih internet izvora i platformi, a tvorenje slivenica i složenica pokazali su se kao najdominantniji morfološki procesi u okviru ispitivanog korpusa. Interpretativni procesi izraza koji imaju vise od jednog značenja analizirani su u okvirima teorije relevancije. Kako je cilj ovog rada da se ispita interpretacija izraza koji imaju specifičnu morfološku strukturu (slivenice i složenice) i kako je razlaganje istih bitan korak u interpretaciji, analiza morfoloških procesa nameće se kao dodatni cilj ovog rada. Evidentno je da postoji veza između morfološke transparentnosti neologizma (mogućnosti da se utvrdi od kojih jezičkih elemenata je izraz sastavljen) i uspešnosti interpretacije datog neologizma na nameravani način, i interpretacija je nesumnjivo lakša u kontekstu, ali je utvrđeno i da je kontekst važan pri interpretaciji složenica (veća transparentnost) kao i kod slivenica (manja transparentnost). Naime, kako bi se došlo do nameravanog značenja izraza, mora se konstruisati ad hoc koncept, te pristupiti enciklopedijskim unosima koncepata koji ulaze u sastav neologizma. Odabir pravih (nameravanih) informacija iz enciklopedijskog unosa, koji postaju delom novostvorenog koncepta, umnogome zavisi od konteksta. Smatra se da je to jedan od razloga što brojni novonastali izrazi u engleskom jeziku imaju više značenja atestiranih u našem korpusu.

Ključne reči: neologizmi, ad hoc koncept, inferencija, slivenice, složenice, teorija relevancije 